YVONNE OLDFIELD

\title{
AUSTRALIA'S GUESTWORKERS? A DISCUSSION OF THE RIGHTS OF NEW ZEALAND CITIZENS TO ENTER, RESIDE AND WORK IN AUSTRALIA
}

\section{LLM RESEARCH PAPER}

LAWS 537

\section{FACULTY OF LAW}

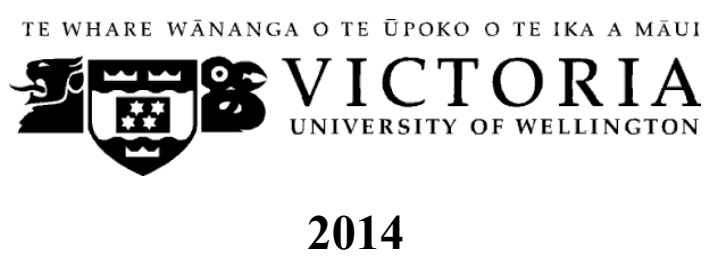




\begin{abstract}
New Zealanders and Australians have enjoyed free movement across the Tasman since early European settlement of both countries. They have been able to live and work in either country for indeterminate periods, and up until recently, enjoyed many of the same benefits as permanents residents of their respective countries. However from 2001 the Australian government has cut back the entitlements of New Zealanders in Australia to welfare and other benefits.
\end{abstract}

This paper explores the legal position of New Zealanders in Australia and the reasons behind the Australian government's moves. It will argue that New Zealanders who do not meet the usual permanent residence criteria are effectively being used as temporary migrant labour in Australia. Even where they make Australia their long-term home they have no access to an alternative path to residence and citizenship. Excluded from the franchise, they are in a position of "civic marginalization" in which they have no direct influence over policies such as the 2001 changes to social welfare.

The paper will conclude by considering briefly whether a human rights approach could provide a mechanism for these "Ozkiwis" to address differential treatment that has arisen as a result of their civic marginalisation.

\title{
Word length
}

The text of this paper (excluding abstract, table of contents, footnotes and bibliography) comprises approximately 7500 words.

\section{Subjects and Topics}

Migration law and policy, migrant workers, human rights. 


\section{Contents}

I Introduction

II The 'right to have rights' within the Australian community

A The Developing Concept of Citizenship

B Migration Policy

III New Zealanders in Australia

A New Zealand migration to Australia

B Eligibility for the Special Category Visa

C Entitlements of Special Category Visa holders

D The temporary nature of the Special Category Visa

IV Discussion

A Temporary migrant workers

B “Civic Marginalisation"

$C$ A rights based approach to addressing differential treatment

V Conclusion

VI Bibliography 


\section{Introduction}

New Zealanders and Australians have benefited from free movement across the Tasman since early European settlement of both countries, enjoying rights to live and work in either place for indeterminate periods. For much of the twentieth century, this caused few issues for either Government. Both started out with strong links, legal and cultural, to their shared British heritage, and both pursued immigration policies which maintained this by giving preference to immigrants of British descent. In addition, because the economies of the two countries thrived for many years, the numbers of migrants were roughly in balance and neither perceived migrants from the other to be a burden.

From the post war period onward this balance started to alter. Australia pursued a policy of population growth which made it necessary to widen its catchment of migrants first to the whole of Europe and eventually to the rest of the world. Notions of Australian identity shifted, with the development of a robust concept of independent citizenship and with multiculturalism winning ground over ties to a British heritage. Meanwhile Australia adopted rigorous procedures for the selection of new permanent residents who would contribute to ongoing growth.

New Zealanders who do not meet these criteria may still enter, reside and work in Australia but are regarded as temporary residents and excluded from many of the social security and other benefits New Zealand citizens in Australia previously enjoyed. This has caused an outcry amongst the significant New Zealand expatriate population in Australia which perceives it as unfair that New Zealanders may live and work in Australia for many years without qualifying for permanent residence. ${ }^{1}$

This paper will start by exploring ideas about inclusion and entitlement within the Australian community, in order to provide some context for discussion of the position of New Zealanders who live and work there. It will outline some relevant features of migration to Australia generally, and of New Zealand migration to Australia in particular. It will then set out in brief the current legal position of New Zealand citizens living in Australia.

${ }^{1}$ Amanda Best "Thousands call for equal rights for expat Kiwis" (28 June 2013) News \& Weather, TV on Demand \&TV Guide TVNZ < www.tvnz.co.nz>. 
It will argue from this that New Zealanders who do not meet the usual permanent residence criteria are effectively being used as temporary migrant labour in Australia, albeit with more benefits than are available to "guest-workers" as that term is normally used. Even where they make Australia their long-term home they have no access to an alternative path to residence and citizenship. Excluded from the franchise as a result, they are in a position of "civic marginalization" in which they have no direct influence over policies such as the 2001 changes to social welfare.

The paper will conclude by considering briefly whether a human rights approach could provide a mechanism for these "Ozkiwis" to address differential treatment that has arisen as a result of their civic marginalisation.

\section{The 'right to have rights' within the Australian community A The Developing Concept of Citizenship}

In its narrowest sense the term citizenship is used to refer to a distinct legal status. Kim Rubenstein says it may also refer to a "political concept" because it is "about the interaction and relationship between individuals, and between the state and individuals". ${ }^{2}$ In its most general sense it denotes membership of a community, with attendant rights and responsibilities. As Judy Fudge puts it: ${ }^{3}$

...citizenship is ... used to refer to a social status that encompasses a broader package of rights and entitlements that is often linked, but not exclusively identified, with legal citizenship. These entitlements are dependent on membership in a national community, and they contemplate a range of degrees of belonging and a spectrum of entitlements that are not necessarily dependent upon an individual's legal citizenship status.

When long-term New Zealand residents of Australia express concern at their exclusion from certain benefits enjoyed by others around them, they are indicating an underlying perception that they are citizens in the broader sense of the term: workers, tax-payers, and perhaps home-owners who participate in, and contribute to, the society in which they live.

\footnotetext{
${ }^{2}$ Kim Rubenstein Australian Citizenship Law in Context (Thomson Lawbook, Sydney, 2002) at 5.

3 Judy Fudge "Precarious Migrant Status and Precarious Employment: The Paradox of International Rights for Migrant Workers" (2012-2013) 34 Comp Lab L \& Pol'y J 95 at 100.
} 
Australian citizenship as a legal concept has developed over the course of the twentieth century (as has that of other former British colonies). The Commonwealth Constitution of 1901 did not make any provision for a concept of citizenship rather, as Crock and Berg point out, "a subject of the Queen born or resident in Australia" continued to be "legally indistinguishable from a British subject". ${ }^{4}$ There was no distinction between the status of British subjects resident in Australia and those resident in New Zealand, and hence no restriction on their movement back and forth across the Tasman, and no distinction made between them upon arrival.

Neither New Zealand nor Australia established independent citizenship until the British Parliament provided for this through the British Nationality Act 1948. ${ }^{5}$ Even with the passing of the Nationality and Citizenship Act 1948 (Cth) citizens of Australia (like their counterparts in New Zealand upon the passing of parallel legislation there) retained their status as British subjects. This meant that: ${ }^{6}$

...As a statutory category 'Australian citizenship' was slow to acquire any substance since legislation underpinning political rights and social benefits continued to specify British subjects, rather than Australian citizens, as the category of eligibility into the 1970s.

Australians finally lost their status as British subjects in 1984, when "belonging to the Australian community finally came to be based on "the notion that membership is conferred through citizenship", 7

In 2002, Kim Rubenstein attempted the "first comprehensive cataloguing of all federal legislation that discriminates between citizens and non-citizens" and observed that the various Acts "reflect mixed messages about citizenship as inclusion and exclusion". ${ }^{8}$ Many benefits are available to citizens as well as others within the Australian community, which in Rubenstein's view "reflects a wider notion of social membership and speaks to the

\footnotetext{
${ }^{4}$ Mary Crock and Laurie Berg Immigration Refugees and Forced Migration: Law Policy and Practice in Australia (The Federation Press, Sydney, 2011) at 18.

${ }^{5}$ Nationality and Citizenship Act 1948 (Cth); British Nationality and New Zealand Citizenship Act 1948 (UK).

${ }^{6}$ National Archives of Australia "Citizenship in Australia: A Guide to Commonwealth Government Records" accessed 8 May 2014 <guides.naa.gov.au>.

7 John Vrachnas and others Migrations and Refugee Law: Principles and Practice in Australia (3rd ed, Cambridge University Press, Melbourne, 2012) at 19.

${ }^{8}$ Rubenstein, above n 2, at15.
} 
normative value of citizenship". ${ }^{9}$ However, she notes that this "is often subject to change" and that "the ideal of universal citizenship is sometimes incorporated through the legal system, but not consistently." 10 As she points out, political membership of the Australian community is restricted by citizenship, with voting rights extended only to citizens. ${ }^{11}$

Given that the franchise itself, along with key rights and benefits, is restricted to Australian citizens, it is pertinent to ask what routes are available for non-citizens to acquire that status. Pursuant to the current legislation, the Australian Citizenship Act (Cth) 2007, Australian citizenship may be acquired through birth, adoption, or descent. ${ }^{12}$ Australian citizenship by birth is not unqualified; unless they have a parent who is a citizen or permanent resident, children born in Australia must remain there for 10 years before they qualify.

Citizenship may also be conferred, at the discretion of the relevant Minister, where certain eligibility requirements are met. A prospective citizen must already be a permanent resident and be likely to continue to reside or maintain close association with Australia. It is also necessary to have English language skills, to be of good character, and to have "an adequate knowledge of Australia and of the responsibilities and privileges of Australian citizenship" (which must be demonstrated by passing an appropriate test).

Like other migrants, New Zealanders seeking citizenship must therefore start by obtaining the prerequisite permanent resident visa. This is in turn dependent on meeting specific criteria determined by Australian migration policy. Crock and Berg assert that discussion of Australian migration policy has always been underpinned by "the expectation that immigration to Australia should be a controlled affair - and the preserve of the executive arm of government as defender of Australian sovereignty": ${ }^{13}$

Australia is a country that was self-consciously 'created' out of a selected population. Migration laws have been vehicles for controlling both entry to territory and, just as importantly, participation in the community.

It now necessary to consider just how migration has been used as a tool in shaping modern Australia

\footnotetext{
9 At 17.

${ }^{10}$ At 17.

${ }^{11}$ Rubenstein, above $\mathrm{n} 2$, at16.

${ }^{12}$ Australian Citizenship Act (Cth) 2007, s21.

${ }^{13}$ Crock and Berg, above n 4, at 17.
} 


\section{B Migration Policy}

Since the beginning of organised colonisation by assisted British migrants in the nineteenth century, immigration debates have been of crucial significance in Australia. Crock and Berg explain: ${ }^{14}$

At the levels of both rational debate and emotive rhetoric, concerns about who comes to this country and on what terms have long been tied closely to broader issues of national identity, economic prosperity and social justice, especially in the local labour market.

Soon after the first British colonists landed, independent migrants from a range of other countries also arrived seeking their fortune on the goldfields. ${ }^{15}$ The British perceived them as a threat, ${ }^{16}$ and as soon as the new Parliament was established in 1901, it enacted a package of laws to restrict their rights to settle permanently. ${ }^{17}$ For decades thereafter: "the fixation was on the racial composition of the migration intake and on the social and cultural identity of the developing society". ${ }^{18}$ Preference for migrants from the United Kingdom persisted until after World War II when it became clear that Canada, the United States and New Zealand were in competition for the same finite pool of potential British migrants. Migrants from a wider range of European countries began to be recruited too, although they were still expected to assimilate - to adopt the language and cultural identity that had been established at Federation.

This period was the most significant period of population expansion for Australia. ${ }^{19}$ Population growth (at levels beyond what was possible by natural increase) was seen, as Katherine Betts has noted, as essential for defence and to supply labour for a developing economy. ${ }^{20}$ The Migration Act 1958 (Migration Act) was enacted to manage this increase

\footnotetext{
${ }^{14}$ Crock and Berg, above $\mathrm{n} 4$, at 3 .

${ }^{15}$ Vrachnas and others, above $\mathrm{n} 7$, at 5.

${ }^{16}$ At 8 .

${ }^{17}$ At 9; see for example the Immigration Restriction Act 1901 (Cth) which created barriers in the form of literacy tests.

${ }^{18}$ Crock and Berg, above $\mathrm{n}$, at 17.

${ }^{19}$ Vrachnas and others, above $\mathrm{n}$ 7, at 11 .

${ }^{20}$ Katherine Betts "Explaining Australian Immigration" (1996) 13 (2) Journal of the Australian Population Association 195 at 201.
} 
in migration, forfeit of the discretion as to who would and would not enter Australia. ${ }^{21}$ For the next thirty years it was the "central plank of migration law" and.:22

...provided the basic machinery to empower the Minister for Immigration and Immigration Department officers to grant, cancel or revoke visas (granted overseas) and entry permits (granted onshore, including to arriving visa-holders) as an exercise of discretion.

The preference for migrants of European origin - the "White Australia" policy- remained unchallenged until the latter part of the twentieth century. In the late eighties the Australian government: ${ }^{23}$

... implemented a carefully structured immigration program which ...designed to maximize Australian interests from migration...The main objective ...to maximize the skill inflow in occupations where shortages exist. By the end of the 1990s Australia's skill program was tightly targeted towards persons with professional and trade skills recognized in Australia, and vocational English capacity ... in the young adult age group and ... occupations where there is evidence of undersupply.

The management of entry to Australia became more controlled from 1989 when the Migration Act was substantially amended. New Regulations followed in 1993 and 1994. From 1 September 1994 all non-citizens entering Australia needed a visa of some sort, thus facilitating tracking and control of new arrivals. This included New Zealanders, who had previously been exempt from any requirement to hold a visa at all. They were now to be granted a type of temporary visa - the Special Category Visa (SCV) - that would permit them to remain in Australia indefinitely. ${ }^{24}$

Along with this, from the 1970 s onwards, came a gradual shift from assimilation to 'integration' and then to 'multiculturalism'. ${ }^{25}$ Today the creation of a multicultural nation is seen by many as a way of demonstrating good international citizenship and as a

\footnotetext{
${ }^{21}$ Crock and Berg, above $\mathrm{n} 4$, at 17.

22 Vrachnas and others, above $n$ 7, at 13.

${ }^{23}$ Bob Birrell and Virginia Rapson "New Zealanders in Australia: The end of an era?" (2001) 9 (1) People and Place 61 at 63.

${ }^{24}$ Vrachnas and others, above n 7, at 122; see also ss 32-34 Migration Act.

25 Betts, above n 20, at 199.
} 
mechanism for strengthening links with neighbouring countries in Asia and the Pacific. Nonetheless the uncomfortable legacy of the 'White Australia' policy means that: ${ }^{26}$

...some views of immigration are informed by racial prejudices and ... some of the stakeholders in that debate are willing to exploit racism if they perceive that they can thus gain an advantage.

(As will be touched on later, this may have contributed to a hardening of attitudes towards New Zealanders entering Australia - since they are no longer overwhelmingly of European ethnicity.)

More recently a further theme has entered migration debates, with support from a very different quarter: the environmental lobby. Given the pressure on Australia's natural resources, water supplies in particular, some have questioned 'growth for growth's sake.' The continued pursuit of population growth has been replaced by the goal of a "sustainable Australia" with cross-party support: ${ }^{27}$

"A key election issue in the 2010 election debate was whether or not we should have a 'Big Australia'. ... Julia Gillard ... rejected the notion... a move ... supported by the Federal Liberal Opposition"

These initiatives towards tighter controls on the numbers coming in to Australia are consistent with the historical approach of firm control over migration generally. There has however been one notable exception to the tight control of migration in Australia - the free movement of New Zealanders into that country.

\section{New Zealanders in Australia}

\section{A New Zealand migration to Australia}

Since Australia and New Zealand were first colonized, the inhabitants of both countries have moved freely back and forth across the Tasman. ${ }^{28}$ Many of the first European settlers to New Zealand came via Australia: Bedford, Ho and Lingard describe the influx of "

\footnotetext{
${ }^{26}$ Vrachnas and others, above $\mathrm{n} 4$, at 13.

27 At 15 .

${ }^{28}$ A. J. Rose "New Zealand Migration to Australia New Zealand” 13 (2) Geographer166.
} 
...former British convicts and their descendants across the Tasman to exploit natural resources ..."29

However people were soon moving the other way too. Writing in 1957 A. J. Rose expressed the prescient view that: ${ }^{30}$

...the tremendous upsurge in the Australian economy during the past decade ... seems likely to offer steadily increasing inducements to the prospective New Zealand immigrant in the years to come.

Until the 1960s the traffic was roughly equal in both directions, and appeared to pose few issues on either side of the Tasman, although it was formalised by the 1973 Trans -Tasman Travel Agreement, ${ }^{31}$ and the 1990 Closer Economic Agreement between Australia and New Zealand. ${ }^{32}$

By the latter part of the twentieth century, however, the growing disparity between the Australian and New Zealand economies saw far greater numbers of New Zealanders going to Australia than vice versa. In the 1990s New Zealanders were the largest single immigrant group in Australia. ${ }^{33}$ Birrell and Rapson note that: ${ }^{34}$

By 1999-2000, New Zealand citizens (including those born in New Zealand and third countries) constituted 34.3 per cent of the total permanent arrivals to Australia in that year...They were by far the single largest source country.

By that time, as we have seen, Australia had imposed strict selection criteria on would-be migrants generally. (As indeed had New Zealand, which by then purported to choose migrants not on the basis of where they came from, as before, but on the basis of the skills

\footnotetext{
${ }^{29}$ Richard Bedford, Elsie Ho and Jacqueline Lidgard "International Migration in New Zealand: Context, Components and Policy Issues" [2002] Joint Special Issue, Journal of Population Research and NZ Population Review at 39.

${ }^{30}$ Above $\mathrm{n} 28$ at 166.

${ }^{31}$ Jacques Poot and Anna Strutt International Trade Agreements and International Migration The World Economy Blackwell Publishing Oxford 2010.

1943.

${ }^{32}$ At 1943.

${ }^{33}$ Alison Green, Mary Power and Deannah Jang “Trans-Tasman Migration: New Zealanders' Explanations for their Move" (2008) 64 New Zealand Geographer 34 at 35.

${ }^{34}$ Birrell and Rapson, above n 23, at 63.
} 
and capital they could bring with them.) ${ }^{35}$ This meant, as Birrell and Rapson point out, that at the same time that Australia otherwise sought to exercise closer control over who entered the country, it had no control over the entry of New Zealanders: ${ }^{36}$

The unregulated New Zealand citizen inflow ....allowed people to come to Australia without reference to ... selection criteria. ... Australia now looks much more attractive, not just to well-trained New Zealanders looking for exciting career opportunities and higher pay that would be received for similar work in New Zealand, but also for relatively low-skilled people. The latter are likely to compete in a tight labour market with similarly placed Australian residents.

From 1 February 2000 was to put New Zealanders "on the same footing as all other permanent residents as regards the two-year waiting period for welfare benefits." 37 Then in 2001 came a more significant move, the effect of which was to distinguish: ${ }^{38}$

...different types of New Zealand citizens - those who fit the Australian Migration Program criteria and those who do not. New Zealand citizens who apply and meet these criteria will be regarded as permanent residents and hence entitled to welfare benefits (after meeting the two-year waiting period). Those who do not, yet still come to Australia after 26 February 2001, will be consigned to a kind of 'indefinite temporary' resident - entitled to work in Australia but not to claim social welfare benefits.

Although, as Birrell and Rapson put it, the "official rhetoric is that the motive was solely to limit Australia's responsibilities for paying Social Security benefits to New Zealand citizens who move to Australia" they and others have speculated that the move was really intended to control who came into that country from New Zealand, since it was suspected that many migrants were using New Zealand as a way station en route to their ultimate destination - Australia. ${ }^{39}$ Bedford Ho and Lingard perceive the underlying intention of the Australian government in this way: ${ }^{40}$

The major concern is not the number of New Zealanders per se entering Australia ...but rather the entry of New Zealanders born in the Pacific Islands or Asia who, some

\footnotetext{
${ }^{35}$ Bedford, Ho and Lingard, above n 29, at 43.

${ }^{36}$ Birrell and Rapson, above n 23, at 63.

37 At 63.

${ }^{38}$ At 63.

${ }^{39}$ Bedford Ho and Lingard, above n 29, at 58.

${ }^{40}$ At 46.
} 
claim, are re-emigrating to Australia in increasing numbers after gaining New Zealand citizenship.

Whatever its purpose, the strategy seemed to have some effect: although the total number of permanent and long-term arrivals in 2000-2001 was higher than at any time prior (which Green et al say was in anticipation of the changes in the law) ${ }^{41}$ trans-Tasman migration subsequently dropped overall as did the proportion of overseas-born New Zealand citizens moving across the Tasman. ${ }^{42}$

For its part, the New Zealand Government has not put up a great deal of opposition. Given fears about the loss of skilled workers to Australia, this is probably unsurprising. As Bedford Ho and Hugo note:

In an era of falling natural increase, and increasing competition for skilled immigrants, the New Zealand diaspora must assume greater significant for policies that have a population dimension. ... The New Zealand Government does see a benefit in staunching the flow to Australia of its citizens who have skills in demand in the New Zealand labour market. It also sees benefit in encouraging return migration of New Zealanders, especially of those with skills.

\section{B Eligibility for the Special Category Visa}

The introduction of the Special Category Visa (SCV) in 1994 was effectively the first step towards formalising the status of New Zealanders coming in to Australia and facilitated their monitoring and control. ${ }^{43}$

The SCV amounts to permission to travel to, enter, and remain in Australia indefinitely and is available to any New Zealand citizen with a New Zealand passport in force provided he or she is not a behavior or health concern. ${ }^{44}$ The SCV continues in force while the holder remains in Australia and comes to an end upon departure. A further SCV will come into effect on the return of the individual to Australia. While it is only one of 52 different visas New Zealanders may apply for, it may be used for entry for essentially any reason,

\footnotetext{
${ }^{41}$ Green and others, above $\mathrm{n} 33$, at 35 .

42 Richard Bedford, Elsie Ho and Graeme Hugo "Trans-Tasman Migration in Context: Recent Flows of New Zealanders Revisited" (2003) 11 (4) People and Place 53 at 54.

${ }^{43}$ Special Category (Temporary) Visa Class TY Subclass 444; see Migration Act 1958 (Cth), s 32.

${ }^{44}$ Migration Act 1958 (Cth), s 32.
} 
including holiday or business trips. ${ }^{45}$ In 2012-2013 over a million New Zealanders made short trips to Australia on the SCV. ${ }^{46}$

Section 501 of the Migration Act 1958 provides that a visa may be declined or revoked on the basis of a behavior concern or on character grounds. Criteria for the exercise of this discretion are set out in a Ministerial Direction no. 55 (the Direction) issued pursuant to s 499 of the Migration Act $1958 .^{47}$

The Direction has the stated aim of "protecting the Australian community from harm as a result of criminal activity or other serious conduct by non-citizens". ${ }^{48}$ The Principles for the exercise of the discretion stress Australia's "sovereign right to determine whether noncitizens who are of character concern are allowed to enter and/or remain in Australia" and describe being able to come to or remain in Australia as $:^{49}$

“...a privilege Australia confers on non-citizens in the expectation that they are and have been, law-abiding, will respect important institutions, such as Australia's law enforcement framework, and will not cause or threaten harm to individuals or the Australian community".

Pursuant to the Direction, a New Zealand citizen who has a "substantial criminal record" (one which has incurred a custodial sentence of 12 months or more) is likely to be declined a visa and/or permanently excluded from Australia. This occurred when Earl Tamou declared prior convictions on his incoming passenger card which the Migration Review Tribunal of Australia. The Tribunal concluded that he was a behavior concern non-citizen who was not entitled to a SCV and could not live in Australia with his family. ${ }^{50}$

In a similar case a young man who wished to join his partner, two small children and other extended family members in Australia was unsuccessful in two separate attempts to obtain a SCV. Upon arriving in Australia in 2008, at which time he went by the name Walker, he failed to declare his previous criminal offending in New Zealand and was subsequently

\footnotetext{
${ }^{45}$ Australian Government Department of Immigration and Border Control "Fact Sheet 17: New Zealanders in Australia" < www.immi.gov.au> accessed 20 June 2014.

${ }^{46}$ Ibid.

${ }^{47}$ Ministerial Direction no 55, issued on 25 July 2012

${ }^{48}$ Direction no 55, Section 6.2 (1).

${ }^{49}$ Direction no 55, Section 6.3 (1).

${ }^{50} 0802005$ [2008] MRTA. See also Weir v Minister for Immigration [2008] FMCA 1230.
} 
declared a behaviour concern non-citizen by the Federal Magistrates Court of Australia. ${ }^{51}$ Two years later, now going by the name Hikuwai, he made a second attempt, this time declaring his convictions, the last of which was seven years earlier when he was 16 years old. He was again declined a SCV. An attempt at judicial review (in which he was not legally represented) failed. ${ }^{52}$

Allowance may be made for those who have "lived in the Australian community for most of their life, or from a very young age" and: ${ }^{53}$

The length of time a non-citizen has been making a positive contribution to the Australian community, and the consequences of a visa refusal or cancellation for minor children and other immediate family members in Australia, are considerations in the context of determining whether that non-citizen's visa should be cancelled..."

This provision will not however save those with a pattern of offending that indicates ongoing risk to the Australian community. In the 2013 case of Smith and Minister for Immigration and Border Protection the Administrative Appeals Tribunal of Australia affirmed a decision to cancel the SCV of a young man of 20 who had come to Australia with his parents in 2006. ${ }^{54} \mathrm{Mr}$. Smith had several convictions in the Children's Court and the County Court of Victoria for offences involving violence and dishonesty. His parents, who had struggled throughout his adolescence to manage his behaviour issues, were faced with returning to New Zealand with him to provide him with ongoing support, and leaving behind the rest of the extended family, including grandchildren, who had become established in Australia.

\section{Entitlements of Special Category Visa holders}

As Birrell and Rapson explain, as late as the 1990s, New Zealanders arriving in Australia were in "a relatively privileged position" in that they were effectively treated as permanent residents whether or not they met any of the normal criteria for permanent residence. ${ }^{55}$ (Although, as noted already, they were excluded from the franchise and employment in the public service since only citizens enjoy these rights.) Even now, where State or Federal

\footnotetext{
${ }^{51}$ Walker v Minister for Immigration [2008] FMCA 1545.

52 Hikuwai v Minister for Immigration [2010] FMCA 643.

${ }^{53}$ Direction no 55, section 6.3(6).

54 Smith and Minister for Immigration and Border Protection [2013] AATA 687.

${ }^{55}$ Birrell and Rapson, above n 23 at 61.
} 
legislation makes express provision to that effect, $\mathrm{SCV}$ holders are eligible for certain of the same benefits available to permanent residents and citizens of Australia.

By way of example, the Fair Entitlements Guarantee Act 2012, which protects the wages of employees by means of a guaranteed advance in cases of employer insolvency, specifically includes holders of Special Category visas, at s 10, in the following terms: ${ }^{56}$

10 Conditions of Eligibility

General Conditions

(1) A person is eligible for an advance if the Secretary is satisfied on the following:

(g) when the employment ended the person was an Australian citizen or, under the Migration Act 1958, the holder of a permanent visa or a special category visa.

In a similar way, the Paid Parental Leave Act 2010 (Cth) provides that to be eligible for parental leave pay a person must satisfy a number of criteria including "the Australian residency test" defined as follows: ${ }^{57}$

When a person satisfies the Australian residency test

(1) A person satisfies the Australian residency test on a day if, on that day, the person:

(a) is an Australian resident; or

(b) is a special category visa holder residing in Australia...

However a SCV remains in force from entry to Australia until exit. The Administrative Appeals Tribunal has recently determined, in an appeal from the Social Security Appeals Tribunal, that this requires that the SCV holder be in the country on each day of the relevant (qualifying) period in order to be eligible for parental leave pay. ${ }^{58}$

Other entitlements are expressed in ways that exclude SCV holders. For example the Higher Education Act provides that student allowances or loans are available only to Australian citizens and permanent humanitarian visa holders. ${ }^{59}$ The legislation providing

\footnotetext{
${ }^{56}$ The Fair Entitlements Guarantee Act 2012 (Cth), s 10.

${ }^{57}$ Parental Leave Act 2010 (Cth), s 45(1); see also Social Security Act 1991 (Cth) ss 7(2).

${ }^{58}$ Lim and Secretary, Department of Social Services [2013] AATA 817.

${ }^{59}$ Higher Education Support Act 2003 (Cth).
} 
for income support, the Social Security Act 1991 (Cth) restricts entitlement to Australian residents, defined in the following terms: ${ }^{60}$

An Australian resident is a person who:

(a) resides in Australia; and

(b) is one of the following:

(i) an Australian citizen;

(ii) the holder of a permanent visa;

(iii) a special category visa holder who is a protected SCV holder.

(This is consistent with the 2001 bilateral social security arrangement between Australia and New Zealand; in this context, a "protected SCV holder" is one resident in Australia prior to 2001).

Other entitlements expressed to be available to permanent residents are also denied to SCV holders, because it is regarded as a temporary visa, as the following case shows.

\section{Temporary nature of the Special Category Visa}

In a 2013 case (Khalid) before the Victoria Civil and Administrative Appeals Tribunal (VCAT) the President was asked to consider an argument that temporary visas are by definition time limited; therefore, because the SCV runs for an indefinite period, it must be a type of permanent visa. ${ }^{61} \mathrm{Mr}$. Khalid, the appellant, was a young New Zealand citizen studying at RMIT University in Melbourne who was advised that as the holder of an SCV he was not eligible for a public transport student concession card. Mr. Khalid challenged this decision. He alleged that it amounted to a breach of the Victorian Equal Opportunity Act and that state's Charter of Human Rights and Responsibilities Act. ${ }^{62}$

That question will be discussed further in the final section of this paper, but the case is also relevant because the President of VCAT, in deciding it, had also to consider whether Mr. Khalid was a "permanent resident of Australia" in terms of the Transport (Compliance and Miscellaneous) Act 1983 (Vic) s 220DA (6) (b) (the Transport Act). This was because the

\footnotetext{
${ }^{60}$ Social Security Act 1991 (Cth), ss 7 (2).

${ }^{61}$ Khalid v Secretary Department of Transport Planning and Local Infrastructure (Human Rights) [2013] VCAT 1839.

${ }^{62}$ Equal Opportunities Act 2010 (Vic), s 125 (c); Charter of Human Rights and Responsibilities Act 2006 (Vic).
} 
Transport Act authorised the exclusion of "overseas students" from the student concession while also stating that a "permanent resident" is not an "overseas student"63

The President found that the holder of an SCV is not a permanent resident. He found that the term 'permanent resident' must be construed as defined in the Australian Citizenship Act 2007 - as the holder of a permanent visa. ${ }^{64} \mathrm{He}$ also noted the provisions of the Migration Act which deal with both permanent and temporary visas and provide that temporary visas holders may enter and remain for a specified period, until a specified event happens or while a holder has a specified status. ${ }^{65}$ It was argued for Mr. Khalid that since New Zealand citizenship is effectively a permanent status the holders of Special Category Visas are effectively permanent residents.

The President did not accept this however, adopting instead the view that since the holder of an SCV would lose it if he or she became a behavior or health concern, the SCV was in the class of temporary visas. He noted that this was consistent with the fact that large numbers of New Zealand citizens entered Australia on an SCV for holiday or business purposes, rather than long-term stay, and so could not be regarded as permanent residents. In a similar vein he considered that staff issuing concession cards needed to be readily able to establish whether someone is a permanent resident: "for example by the production of copy documents which show the visa status of the applicant". ${ }^{66}$ He also quoted the Minister for Public Transport as saying: ${ }^{67}$

Citizenship and residency are commonly used as criteria for eligibility to taxpayerfunded benefits, such as welfare and health care. The reason is simple. Provision of a particular taxpayer-funded benefit cannot be considered in isolation. It must be considered in the context of the taxation and welfare schemes as a whole. It is fair and reasonable to exclude visitors and temporary residents from receiving taxpayer-funded benefits (welfare schemes, health care et cetera), because their residency status is such that they do not participate in or contribute to the taxation scheme in the same way as long-term or permanent residents or Australian citizens.

\footnotetext{
63 Transport (Compliance and Miscellaneous) Act (Vic) 1983, s 220 DA (6).

${ }^{64}$ Australian Citizenship Act 2007 (Cth), s 5.

${ }^{65}$ Migration Act 1948 (Cth), s 30.

${ }^{66}$ Khalid, above n 61, at [86].

${ }^{67}$ At [49] quoting Second Reading Speech of the Honourable Lyn Kosky MP, Minister for Public Transport, See Victoria, Parliamentary Debates, Legislative Assembly, 20 September 2007, 3201
} 
Counsel for Mr. Khalid had argued that SCV holders such as Mr. Khalid were "long term" residents of the type mentioned here. (Certainly some non-protected SCV holders may have had many years of paying tax.) The argument was however rejected. The President found that Mr. Khalid "cannot be regarded as a permanent resident of Australia, as he has not sought, let alone obtained, any kind of permanent visa entitling him to permanent residency'. ${ }^{68}$

\section{Discussion}

\section{A Temporary migrant workers}

As we seen from Khalid, holders of Special Category Visas are not classed as permanent residents of Australia. News media and politicians sometimes describe them, instead, as "guest workers": 69

Kiwis should get used to being Australia's "guest workers" for the foreseeable future, Prime Minister John Key said after the conclusion of his annual bilateral talks with his Australian counterpart. Key said he would be "staggered" if the Australian government reversed its 2001 welfare changes any time soon...

This, however, is probably something of a misnomer given the way this label has traditionally been used. Guest worker programmes are explained by Lenard and Straehle in the following terms: ${ }^{70}$

In general, guest-worker programmes invite foreign nationals to work temporarily in an industry that is experiencing labour shortages (of either high- or low-skilled workers). In most countries with guest-worker programmes, employers must demonstrate that they have attempted to recruit citizens for these jobs, but that no citizens were available to do so ...

As these authors point out, guest-work programmes differ in many ways but all limit the time that guest workers may live and work in the receiving country. Many restrict movement between employers and all make it clear that guest work is not a track to achieving permanent residence. Examples include the original Gastarbeiter scheme which 
drew mainly Turkish migrants to post-war Germany and the United States Bracero programme which ran during much the same period and pulled Mexican farm labourers into the United States on a seasonal basis to fill gaps in the agricultural labour market. ${ }^{71}$

Ruhs and Martin explain that guest work programmes are "once again in vogue" because they are seen as a way of balancing conflicting views about the use of migrant labour: ${ }^{72}$

Governments that face public opposition to labor immigration often see guest worker programs - which, by design, increase migrant numbers but restrict migrant rights as the best compromise between the extremes of no borders and no migrants. ...

...With worries about ...the fiscal and social costs of immigration ....receiving country governments find it appealing to use guest worker programs to "borrow" workers from lower-wage countries, and to restrict the rights of migrants in order to minimize their costs.

New Zealand has its own guest-workers, including the seasonal workers coming to work in the Recognised Seasonal Employer Category (RSE) and the holidaymakers who are able to do such work as fruit picking under the Supplementary Seasonal Employment Category. $^{73}$

Australian has a similar counterpart in the subclass 457 visa has been described by an Australian commentator as a "robust and sophisticated legislative program" which balances both the need to fill short term labour shortages and the need to "protect Australian jobs, wages and conditions and to protect foreign workers from exploitation". 74 It purports to achieve these goals by mechanisms that ensure that workers on 457 visas are hired only for jobs for which no Australians are available, at pay rates that do not undercut wages paid by competing firms.

Clearly New Zealanders entering Australia on Special Category Visas, with rights to live and work indefinitely, and complete freedom of movement, are not "guest-workers" in the very specific way that that term is used. It is more appropriately applied to holders of

\footnotetext{
${ }^{71}$ At 208.

72 Martin Ruhs and Philip Martin "Numbers vs Right: Trade-Offs and Guest Worker Programs” (2008) 42

(1) IMR 249 at 260.

73 Immigration Act (Cth) 2009, s 70 (b) (i).

74 Maria Jockel (2009) “457 Visas, Skill shortages and worker protection” (2) 17 People and Place 41 at 41.
} 
subclass 457 visas. Although space precludes a discussion of the relevant provisions, SCV holders employed in Australia are also covered by State and Federal labour laws.

However those who are not well placed to gain permanent residence and (eventually) citizenship - those who have come to Australia in search of work in low or semi-skilled areas - can nonetheless be regarded (in a more general way) as temporary migrants.

In the period since the 1980s, an increasing proportion of the movement into Australia has been short term or temporary migration. ${ }^{75}$ In this, Australia is no different to any other receiving country. Katherine Betts notes that "changes in the world economy" both impel increasing numbers to migration while also making it more feasible, with consequent increases in temporary migration all over the world. ${ }^{76}$

Betts points to labour market theories to explain the circumstances in which temporary but not permanent - migration might be encouraged. Summarising Castles and Kosacks 1973 'reserve army theory' she explains: ${ }^{77}$

...if a reserve army of unemployed workers exists, these workers can be drawn into the workforce during times of prosperity, thus reducing pressure on wages. (When the next downturn occurs, they can be pushed out again.)...However ... a reserve army of adult citizens becomes politically dangerous. It is more effective for business interests to draw on foreigners, bringing them into the country during the booms and sending them back during the busts.

This analysis can readily be applied to New Zealanders crossing the Tasman to find work. For over twenty years the Australian economy has been doing better than that of New Zealand. This growth has been accompanied by an increasing disparity in the pay rates of the two countries, enticing New Zealanders across the Tasman and giving Australia the benefit of a pool of literate, English-speaking workers from which to fill shortages in its labour market.

Research by Green, Power and Jang shows that "despite frequently expressed concerns that New Zealand loses its best and brightest to Australia, New Zealanders in Australia are

75 Betts, above n 20, at 218, quoting Hugo 1996.

${ }^{76}$ At 210.

${ }^{77}$ At 210. 
representative of the entire population". ${ }^{78}$ They have also confirmed that the lure of higher pay has been a significant 'pull' factor for New Zealanders moving to Australia: ${ }^{79}$

New Zealand migrants to Australia were influenced by economic factors in their decisions to migrate... They move to Australia because they find it attractive and perceive it to have opportunities not available in New Zealand.

While some of these trans-Tasman migrants meet the selection criteria for residence and so have the opportunity for full inclusion in the Australian community, many of the rest are effectively temporary migrant workers. With restricted access to social support, they have a place in Australia only while they serve its labour market needs. If they find themselves facing unemployment through illness or redundancy, they may have little choice, in the absence of welfare assistance, but to return home. Long-term residents they may be, but by no means permanent.

\section{B 'Civic marginalization'}

Discussing CER, Poot and Strutt have suggested that the "asymmetric treatment" of New Zealanders and Australians in each other's countries shows: "how difficult it can be to lock in migration agreements". ${ }^{80}$ In 2012 the Productivity Commissions of Australia and New Zealand conducted a joint study on ways to increase economic integration between the two countries and improve economic outcomes for both. Their report identified issues faced by "long term resident non-Protected Special Category Visa holders" who had "paid taxes for many years" in relation to their lack of access to social welfare, student loans for their children. ${ }^{81}$ It recommended that these issues be addressed by means of "a pathway for New Zealand citizens living long term in Australia to achieve permanent residency and/or citizenship" and provision of student loans to New Zealand citizens. ${ }^{82}$

In response, the Governments of New Zealand and Australia have noted that Australia will "extend access to student loans under the Higher Education Loan Program (HELP) to long-

\footnotetext{
${ }^{78}$ Green and others, above n 33 , at 35 .

79 At 43.

${ }^{80}$ Poot and Strutt, above n 31, at 1944.

81 Australian Productivity Commission and New Zealand Productivity Commission 2012, Strengthening Trans-Tasman Economic Relations, Joint Study, Final Report.

${ }^{82}$ At 12.
} 
term New Zealand residents in Australia as announced in 2013." ${ }^{\prime 83}$ Otherwise, however, nothing is to change: ${ }^{84}$

"New Zealanders ...have access to a number of Government-funded services including Medicare. ...There are permanent visa options for New Zealand Citizens creating the pathway for permanent residency....

It is not expected that existing arrangements will be changed in the near future.

And the Australian prime minister was recently reported as saying: ${ }^{85}$

Abbot made it clear Kiwis enjoying the freedom to live and work across the Tasman would not be allowed to become welfare recipients. Questioned over the fairness of Kiwis paying taxes across the ditch without any of the benefits, Abbott said they were lucky to be given access to a life in Australia.

Clearly there is no political will to extend full social welfare protections to long term SCV holders, or to offer an alternative track to permanent resident status which is linked to the length of time SCV holders have lived, worked and paid taxes in Australia, rather than the usual skills based criteria.

Lenard and Straehle argue that where guest workers and other temporary workers are vulnerable to exploitation, it is as a consequence of their "formalised second-class status" - their exclusion from full civil and political rights in the countries in which they work temporarily. ${ }^{86}$ They suggest that because guest workers "are affected by the political decisions made in the receiving country" without having input into these decisions, ${ }^{87}$ temporary work programmes fail to conform to: ${ }^{88}$

... a key liberal democratic principle, that is, the principle that all individuals are entitled to participate meaningfully and as equals in the political environment in which they reside for extended periods of time.

\footnotetext{
${ }^{83}$ New Zealand Australia Joint Response to Productivity Commission Report at [4.25].

${ }^{84}$ At [4.24]

85 Tracy Watkins “Kiwis 'guest workers' in Australia' - Key” (9 Feb 2014) Stuff <www.stuff.co.nz >

${ }^{86}$ Lenard and Straehle, above n 70, at 211.

${ }^{87}$ At 215.

${ }^{88}$ At 223.
} 
They argue that only access to citizenship rights can provide "full inclusion in the receiving society" and that without it temporary workers "will ultimately remain vulnerable to... rights violations..." 89

This is consistent with Betts' comments (quoted above) about the theory of a reserve labour army. David Owen also speaks of "the civic marginalization of migrants" relative to the "norm of equal membership in the democratic state". ${ }^{90} \mathrm{He}$ too considers it critical to ask whether "a given class of migrants has a clear route to citizenship" because "it makes a normatively consequential difference". He argues that "habitual residents ... should ...enjoy a route to national citizenship" and that in relation to those who do not (such as temporary migrants) "the state has an additional duty of care" ${ }^{91} \mathrm{He}$ also considers that “... socio-economic rights should be broadly available to migrants other than first-time shortterm workers who are exempt from a duty to contribute to the state".

Achieving the latter seems inevitably linked to the first given that migrants who do not have the civil and political rights attendant on citizenship cannot influence economic and welfare policy. This is, of course, exactly the position of many New Zealand citizens living long term in Australia. Perceiving themselves members of the Australian community, but lacking the vote, they have been powerless in the face of curtailment of their access to a number of socio-economic rights.

In this context, it might be necessary to turn to a rights-based strategy to assist SCV holders who are unable to address their concerns through civic engagement.

\section{A Human Rights Approach}

Acknowledging that civic marginalization may see migrants (or their advocates) without tools to address their concerns, Owen considers that - even at the risk of impinging somewhat on national sovereignty - "human rights should be available to all migrants on

\footnotetext{
${ }^{89}$ At 223.

${ }^{90}$ David Owen "Citizenship and the Marginalities of Migrants" (2013) 16 (3) Critical Review of International Social and Political Philosophy 326 at 328.

${ }^{91}$ At 341.
} 
reasonable terms of exercise". ${ }^{92}$ Looking more specifically at migrant workers, Judy Fudge notes that some migration statuses may be highly precarious and suggests that: ${ }^{93}$

International human rights norms offer a more promising avenue for protecting migrant workers than do claims based upon citizenship...Human rights are invoked and apply on the basis of humanity and personhood, a much broader status that does not depend upon political membership in the host state. The United Nations (UN) and the International Labour Organisation (ILO) advocate a rights-based approach to managing temporary migration programs.

Two ILO conventions address the rights of migrant workers: Convention 97 (Migration for Employment (Revised) (1949)) and Convention 143 (Migrant Workers (Supplementary Provisions) (1975)). In each, Article 11 defines a migrant worker as: "a person who migrates or who has migrated from one country to another with a view to being employed other than on his own account" and both conventions provide that social security protections should be available to migrant workers in the same way that they are to others. ${ }^{94}$ It can be argued therefore that New Zealanders who remain in Australia for work - the temporary migrant workers that this paper has focussed on - are captured within the definition in Article 11 of each of the ILO Conventions.

The United Nations has also sought to protect the rights of migrant workers by means of the Convention of the Protection of the Rights of All Migrant Workers and Members of their Families (ICRMW) ${ }^{95}$ Like the relevant ILO conventions, the ICRMW includes a requirement that migrant workers are able to access the same benefits, under local social security regimes, as other workers. ${ }^{96}$ However very few receiving countries have ratified this convention - and Australia is not one of them. Nor has it ratified the two ILO conventions on migrant labour. Fudge explains that: ${ }^{97}$

The major obstacles to migrant-receiving countries ratifying these conventions are the complexity and dynamism of a country's immigration legislation and practice, [and] the reluctance to enter into multilateral commitments in the area of policy regarding foreigners...

\footnotetext{
${ }_{92}$ Owen, above $\mathrm{n} 90$, at 341.

${ }^{93}$ Fudge, above $\mathrm{n} 3$, at 96

${ }^{94}$ Article 6 provides for equal treatment of migrant and national workers in respect of both working conditions and social security. Article 10 of the 1975 Convention also provides for social security.

${ }^{95}$ General Assembly Resolution 45/158 Dec 181990.

${ }^{96}$ Art 25-27.

${ }^{97}$ Fudge, above n 3, at 126.
} 
In response to the low ratification of existing conventions, and their potential ineffectiveness, the ILO adopted a Multilateral Framework on Labor Migration in 2006. ${ }^{98}$ Principle 9(c) provides that domestic law (of receiving countries) should be guided by relevant ILO standards in respect of social security, while Guideline 9.9 provides that bilateral agreements should provide for "social security coverage and benefits" and portability. However it merely sets out "nonbinding principles and guidelines for a rights based approach to migration".

Since Australia has not ratified the ILO and UN conventions on migrant labour, and the Framework is a soft law approach, these mechanisms are of no assistance to New Zealanders in Australia.

More general human rights instruments might be. Castles notes that in the European context "strong legal systems and international human rights instruments" have the result that:

Migrants - even those officially considered to be temporary - gain welfare entitlements and acquire civil and political rights. It is very hard for democratic countries to force former guest workers to leave.

It is beyond the scope of this paper to attempt a discussion of the success of the use of other human rights instruments in comparable situations in Europe or elsewhere. Suffice to note the recent (unsuccessful) attempt to do so in Australia in Mr. Khalid's case.

As noted already, Mr. Khalid claimed that denying him student concession on public transport was a breach of the Equal Opportunity Act 2010 (Vic) (EO Act), s 44 of which prohibits discrimination in the form of a refusal to provide goods and services to another person on account of their race. Race is defined at s 4 of the EO Act to include nationality or national origin.

The President of VCAT found that "the existence of New Zealand citizenship is the substantial reason for the treatment. There is direct discrimination based on nationality, and therefore race as defined in the EO Act." 99

\footnotetext{
${ }^{98}$ ILO International Migration Programme "ILO's Multilateral Framework on Labour Migration: Nonbinding principles and guidelines for a rights-based approach" Geneva, International Labour Office, 2006.

${ }^{99}$ Khalid, above $n$ 61, at [42]. Reference is also made therein to Sydney University Postgraduate Representative Association (SUPRA) v Minister for Transport Services [2006] NSWADT 83 [41].
} 
He then turned his mind to the question of whether the Department of Transport Planning and Local Infrastructure was entitled to construe the Transport Act as it had, given that to do so abrogated rights under the EO Act. He noted that s 32 (1) of Charter of Human Rights and Responsibilities Act 2006 (Vic) directed that:

So far as it is possible to do so consistently with their purpose, all statutory provisions must be interpreted in a way that is compatible with human rights.

However, in this case, he concluded that: ${ }^{100}$

Given that the vast majority of special category visa holders are short-term arrivals only, a construction of the expression 'permanent resident of Australia' which included all holders of special category visas would not be consistent with the object of the Transport Legislation Amendment Bill 2007.

\section{Conclusion}

New Zealanders are treated no differently from other would-be migrants who seek permanent residence in Australia. They are subject to the same type of process that other new arrivals must face, or was faced by the parents or grandparents of today's Australian citizens. Even those long-term resident New Zealanders who fail to meet the criteria for permanent residence, remain relatively privileged. Subject to character and health requirements they may live and work in Australia indefinitely and may access some key benefits such as Medicare, paid parental leave, and redundancy pay guarantees.

To use the word "guest-worker" in respect of these migrants is, as already acknowledged, somewhat of a misnomer. It remains however that they are permitted to stay and make a contribution to the Australian economy for extended periods without at any stage relying on the fact extended residence as a qualifying ground for a permanent residence visa. Despite paying taxes, possibly for many years, they will find that in the event of ill health or redundancy, they are unable to access any form of state support. In times a downturn in the Australian economy, they will be surplus to requirements, and have little option but to return to New Zealand. Disenfranchised, they are in a genuinely precarious position.

${ }^{100}$ At $[84 \mathrm{e}]$. 
In circumstances of marginalisation, it seems appropriate to turn to human rights instruments for a remedy. Because Australia, like many other receiving countries, has failed to ratify the key migrant workers conventions it seems that resort to wider human rights might be necessary. Khalid shows however that such an approach may well have limited success. 


\section{BIBLIOGRAPHY}

\section{PRIMARY SOURCES}

\section{A Cases}

Australia

0802005 [2008] MRTA 525.

Hikawai v Minister for Immigration [2010] FMCA 643.

Khalid v Secretary Department of Transport Planning and Local Infrastructure (Human Rights) [2013] VCAT 1839.

Lim and Secretary Department of Social Services [2013] AATA 817.

Smith and Minister for Immigration and Border Protection [2013] AATA 687.

Walker v Minister for Immigration [2008] FMCA 1545.

Weir v Minister for Immigration [2008] FMCA 1230.

\section{B Legislation}

New Zealand

British Nationality and New Zealand Citizenship Act 1948;

Australia

Australian Citizenship Act 2007 (Cth).

Charter of Human Rights and Responsibilities Act 2006 (Vic).

Commonwealth Constitution 
Equal Opportunity Act 2010 (Vic).

Fair Entitlements Guarantee Act 2012 (Cth).

Higher Education Support Act 2003 (Cth).

Migration Act 1958 (Cth).

Migration Reform Act 1992 (Cth).

Nationality and Citizenship Act 1948 (Cth).

Paid Parental Leave Act 2010 (Cth).

Transport (Compliance and Miscellaneous) Act 1983 (Vic).

Social Security Act 1991 (Cth).

United Kingdom

British Nationality Act 1948

\section{International Conventions}

International Labour Organisation Convention 97 Migration for Employment (Revised) (1949).

International Labour Organisation Convention 143 Migrant Workers (Supplementary Provisions) (1975).

ILO International Migration Programme “ILO's Multilateral Framework on Labour Migration: Non-binding principles and guidelines for a rights-based approach" Geneva, International Labour Office, 2006. 
UN Convention of the Protection of the Rights of All Migrant Workers and Members of their Families (ICRMW). (General Assembly Resolution 45/158 of Dec 18 1990; came into effect July 12003.

\section{E Government Reports}

Australian Productivity Commission and New Zealand Productivity Commission 2012, Strengthening trans-Tasman economic relations, Joint Study, Final Report.

\section{SECONDARY SOURCES}

\section{A Books and Chapters in Books}

Mary Crock and Laurie Berg Immigration Refugees and Forced Migration: Law Policy and Practice in Australia (The Federation Press, Sydney, 2011).

Jacques Poot and Anna Strutt International Trade Agreements and International Migration The World Economy Blackwell Publishing Oxford 2010.

Kim Rubenstein Australian Citizenship Law in Context (Thomson Lawbook, Sydney, 2002).

John Vrachnas and others Migrations and Refugee Law: Principles and Practice in Australia (3rd ed, Cambridge University Press, Melbourne, 2012).

\section{B Journal Articles}

Richard Bedford, Elsie Ho and Graeme Hugo "Trans-Tasman Migration in Context: Recent Flows of New Zealanders Revisited” (2003) 11 (4) People and Place 53. 
Richard Bedford, Elsie Ho and Jacqueline Lidgard "International Migration in New Zealand: Context, Components and Policy Issues" [2002] Joint Special Issue, Journal of Population Research and NZ Population Review.

Katherine Betts "Explaining Australian Immigration" (1996) 13 (2) Journal of the Australian Population Association 195.

Bob Birrell and Virginia Rapson "New Zealanders in Australia: The end of an era?” (2001) 9 (1) People and Place 61.

Stephen Castles "Guestworkers in Europe: A Resurrection?" (2006) 40 (4) The International Migration Review 741.

Judy Fudge "Precarious Migrant Status and Precarious Employment: The Paradox of International Rights for Migrant Workers” (2012-2013) 34 Comp Lab L \& Pol’y J 95.

Alison Green, Mary Power and Deannah Jang “Trans-Tasman Migration: New Zealanders' Explanations for their Move" (2008) 64 New Zealand Geographer 34.

Maria Jockel (2009) “457 Visas, Skill shortages and worker protection” (2) 17 People and Place 41.

Patti Tamara Lenard and Christine Straehle "Temporary labour migration, global redistribution, and democratic justice" (2011) 11 (2) Politics, Philosophy \& Economics 206.

Patrick Ongley and David Pearson "Post-1945 International Migration: New Zealand, Australia and Canada Compared" (1995) 29 (3) The International Migration Review 765.

David Owen "Citizenship and the Marginalities of Migrants" (2013) 16 (3) Critical Review of International Social and Political Philosophy 326.

Virginia Rapson "Welfare Payments and New Zealand Migration: Myth and Reality" (1995) 4 (2) People and Place 34.

A. J. Rose "New Zealand Migration to Australia New Zealand" 13 (2) Geographer166. 
Martin Ruhs and Philip Martin "Numbers vs Right: Trade-Offs and Guest Worker Programs" (2008) 42 (1) IMR 249.

\section{Internet materials}

<australia.gov.au/about-australia/our-government/australias-federation> accessed 6 May.

<guides.naa.gov.au/citizenship/chapter1/citizenship-australia.aspx > accessed 8 May.

<www.immi.gov.au/media/fact-sheets/79-ministerial-direction-55.pdf>

<transtasman-review.productivity.govt.nz>

< www.immi.gov.au/media/fact-sheets $>$ 